\title{
PERANCANGAN DAN IMPLEMENTASI SISTEM INFORMASI PERPUSTAKAAN DI PROGRAM STUDI TEKNIK LINGKUNGAN FAKULTAS TEKNIK UNDIP
}

\author{
Lia Dorothy ${ }^{1)}$, Kodrat Iman Satoto ${ }^{2)}$, Oky Dwi Nurhayati ${ }^{2)}$ \\ Jurusan Sistem Komputer, Fakultas Teknik, Universitas Diponegoro \\ J1. Prof. Sudharto, Tembalang, Semarang, Indonesia \\ Email : liadorothy@live.com
}

\begin{abstract}
Abstrak
Perkembangan teknologi informasi menciptakan keunggulan kompetitif dalam berbagai bidang. Perkembangan ini didukung oleh industri perangkat keras dan perangkat lunak komputer yang terus berkembang, yakni dengan pengaksesan dan pemrosesan informasi yang cepat, akurat, dan efisien melalui sebuah sistem informasi. Pengelolaan data buku di perpustakaan Teknik Lingkungan masih dilakukan menggunakan microsoft office excel, sedangkan pengelolaan data anggota dan data peminjaman masih dicatat secara manual. Oleh karena itu, diperlukan sebuah penelitian untuk membangun sebuah sistem informasi perpustakaan yang dapat mempermudah pengelolaan data dan aktivitas perpustakaan di Program Studi Teknik Lingkungan. Sistem informasi perpustakaan terkomputerisasi ini diharapkan dapat membantu pengelolaan data buku dan data anggota, transaksi peminjaman dan pengembalian buku, serta menghasilkan laporan untuk keperluan administrasi perpustakaan, sehingga dapat meningkatkan efektifitas kinerja karyawan.

Sistem informasi perpustakaan ini berbasis web, dikembangkan dengan bahasa pemrograman PHP dan basis data MySQL, serta menggunakan framework CodeIgniter. Sistem informasi ini juga dilengkapi dengan barcode reader yang digunakan untuk mempermudah pengelolaan data buku. Penelitian dikembangkan dengan metode SDLC (System Development Life Cycle). Langkah-langkah penelitian meliputi tahap perencanaan, tahap analisis, tahap perancangaan, tahap implementasi, tahap pengujian, dan tahap pemeliharaan. Sistem dirancang dengan menggunakan diagram UML (Unified Modelling Language) dan diuji dengan pengujian kotak hitam (blackbox testing).

Seтua menu dalam sistem informasi perpustakaan dan barcode reader dapat bekerja dengan baik. Sistem informasi perpustakaan telah diimplementasikan di Program Studi Teknik Lingkungan Fakultas Teknik UNDIP. Sistem informasi ini menambah kualitas pelayanan pada perpustakaan Teknik Lingkungan.
\end{abstract}

Kata kunci : Teknologi informasi, perangkat keras, perangkat lunak, microsoft office excel, sistem informasi perpustakaan, PHP, MySQL, CodeIgniter, barcode reader, SDLC, UML, blackbox testing.

\section{PENDAHULUAN}

Pengelolaan data dan aktivitas perpustakaan yang masih dilakukan secara manual menjadi latar belakang dibangunnya sebuah sistem informasi perpustakaan. Sistem informasi yang terkomputerisasi dapat membantu proses pengelolaan aktivitas perpustakaan seperti proses pengelolaan data buku dan data anggota, proses pengelolaan transaksi peminjaman dan pengembalian buku, serta pembuatan laporan. Sistem informasi juga dapat melakukan pemrosesan data dengan lebih cepat, serta menghasilkan informasi yang aktual dan akurat.

Tujuan dari pembuatan tugas akhir ini adalah membuat sebuah sistem informasi perpustakaan yang memudahkan aktivitas seperti pengelolaan data buku dan anggota, transaksi peminjaman dan pengembalian buku di perpustakaan melalui aplikasi berbasis 
komputer, sehingga dapat meningkatkan efisiensi dan efektifitas kinerja karyawan.

Berdasarkan latar belakang dan tujuan diatas, didapatkan rumusan permasalahan yang akan diselesaikan dalam penelitian tugas akhir ini, yaitu bagaimana merancang sebuah sistem informasi perpustakaan berbasis web di Program Studi Teknik Lingkungan, Fakultas Teknik, UNDIP yang akan mempercepat pengelolaan data dan aktivitas perpustakaan sehingga dapat meningkatkan efisiensi dan efektifitas kinerja karyawan?

\section{LANDASAN TEORI}

\subsection{Sistem Informasi}

Sistem informasi adalah suatu sistem yang terdiri dari beberapa komponen yang bekerja bersama untuk mengumpulkan data dan instruksi, memproses dan mengolahnya, serta menampilkan data yang sudah diolah tersebut menjadi informasi. Sistem informasi dalam suatu organisasi dapat mempertemukan kebutuhan pengolahan transaksi harian yang mendukung fungsi operasi organisasi yang bersifat manajerial dengan kegiatan strategi dari suatu organisasi untuk dapat menyediakan informasi yang diperlukan untuk pengambilan keputusan. Sistem informasi dalam suatu organisasi dapat dikatakan sebagai suatu sistem yang menyediakan informasi bagi semua tingkatan dalam organisasi kapanpun informasi tersebut diperlukan. Sistem ini menyimpan, mengubah, mengolah, dan mengkomunikasikan informasi yang diterima dengan menggunakan sistem informasi atau peralatan sistem lainnya.

Menurut Mahamudu (2010), sistem informasi terdiri atas komponen-komponen, yaitu komponen masukan, komponen model, komponen keluaran,komponen teknologi, komponen perangkat keras, komponen perangkat lunak, komponen basis data, dan komponen kontrol.

Sistem informasi perpustakaan adalah perangkat lunak yang didesain sesuai dengan proses bisnis perpustakaan, yang digunakan untuk melayani transaksi pendataan koleksi perpustakaan, peminjaman, perpanjangan, dan pengembalian buku, dan pembuatan laporan secara berkala guna mendukung pengambilan keputusan yang membantu proses manajerial perpustakaan.

\subsection{Basis Data}

Basis data adalah kumpulan dari berbagai data/informasi yang saling terintegrasi dan berhubungan satu sama lain, disimpan di dalam perangkat keras (komputer) secara sistematis dan tanpa redundansi dan dapat diolah menggunakan perangkat lunak. Perangkat lunak yang digunakan untuk mengelola dan memanggil kueri basis data disebut sistem manajemen basis data (Database Management System) (Date, 2000).

DBMS digunakan untuk membangun sebuah sistem basis data yang berbasis komputer. DBMS didesain untuk menangani pengelolaan dan penggunaan dari suatu kumpulan data, serta memungkinkan pengguna untuk mendefinisikan, membuat, memelihara, dan mengendalikan akses terhadap sistem basis data, sehingga DBMS dapat digunakan sesuai kebutuhan. Menurut Connolly dkk. (2000), ada lima komponen Sistem Manajemen Basis Data (DBMS), yaitu : Perangkat keras, perangkat lunak, data, prosedur, dan manusia.

MySQL merupakan software yang tergolong database server yaitu sebuah program yang berfungsi untuk mengolah, menyimpan dan memanipulasi data dari server. MySQL bersifat open source, sehingga software ini dilengkapi dengan source code (kode yang dipakai untuk membuat MySQL), bentuk executable code-nya dapat dijalankan secara langsung dalam sistem operasi. MySQL merupakan multiuser database yang menggunakan bahasa Structured Query Language (SQL) dan menggunakan konsep Relational Database Management System (RDBMS) dimana sebuah tabel merupakan struktur penyimpanan dasar. Satu tabel atau lebih membentuk sebuah basis data relasional. MySQL didistribusikan secara gratis di bawah lisensi GPL (General Public Licence) (Kadir, 2009). 


\subsection{Hypertext Preprocessor (PHP)}

PHP didefinisikan sebagai bahasa pemrograman berbasis web yang memiliki kemampuan untuk memproses data dinamis. PHP merupakan skrip yang dijalankan di server, dimana kode yang menyusun program tidak perlu diedarkan ke pemakai sehingga kerahasiaan kode dapat dilindungi. PHP didesain khusus untuk aplikasi web. PHP disebut bahasa sisi server (server-side embedded script language), maka sintaks dan perintah PHP akan dieksekusi di server, sehingga dikirimkan ke browser adalah "hasil jadi" dalam bentuk HTML. PHP termasuk Open Source Product dan saat ini telah mencapai versi 5. PHP dapat berjalan di berbagai Web Server seperti IIS, Apache, PWS, dan lain-lain (Kadir, 2008).

Pada prinsipnya server akan bekerja apabila ada permintaan dari client. Dalam hal ini client menggunakan kode-kode PHP untuk mengirimkan permintaan ke server. Ketika menggunakan PHP sebagai server-side embedded script language, maka server akan melakukan hal-hal sebagai berikut :

1. Membaca permintaan dari client atau browser.

2. Mencari halaman/page di server.

3. Melakukan instruksi yang diberikan oleh PHP untuk melakukan modifikasi pada halaman/page.

4. Mengirim kembali halaman tersebut kepada client melalui internet atau intranet.

Skema kerja PHP ditunjukkan oleh gambar 1 berikut :

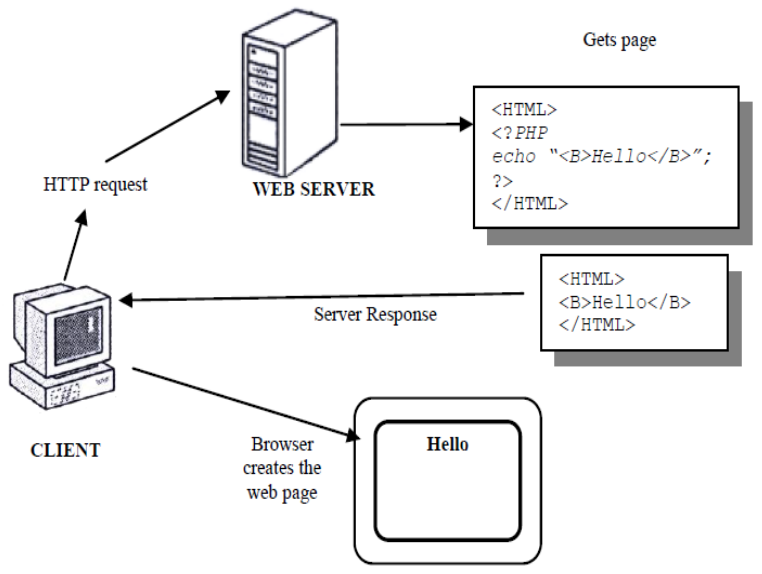

Gambar 1 Skema Kerja PHP

\subsection{CodeIgniter}

CodeIgniter (CI) adalah framework / kerangka kerja pengembangan aplikasi (Application Development Framework) dengan menggunakan PHP. CI merupakan kerangka kerja yang menggunakan lisensi open source Apache/BSD. CI dikembangkan pertama kali oleh Rick Ellis (Sidik, 2012).

CI memungkinkan pengembang untuk menghasilkan program dengan cepat, dengan mengikuti kerangka kerja yang telah ada, sehingga pengembang tidak perlu membuat program dari awal (from scracth). CI menyediakan sekumpulan librari atau fungsifungsi yang terorganisasi dan diperlukan untuk membuat program dengan cepat. Selain itu, CI menggunakan antarmuka dan struktur logika yang sederhana untuk mengakses librarinya. Pengembang hanya perlu memasukkan data yang akan diproses dan berfokus pada kode yang harus dibuat untuk menyelesaikan suatu pekerjaan (User Guide Code Igniter).

Kerangka kerja CI menggunakan kaidah Model-View-Controller (MVC). MVC adalah sebuah perangkat lunak yang memisahkan antara aplikasi logika dan presentasi pada halaman web. Skrip PHP, query MySQL, Javascript dan CSS bisa saling terpisah, sehingga tidak membutuhkan sumber daya yang besar untuk mengeksekusinya. Halaman web akan terdiri dari sedikit kode, karena sudah terjadi pemisahan antara tampilan dan pemrograman.

Dalam konsep MVC, kode program dapat dibagi menjadi tiga kategori, yaitu : Model merupakan struktur data. Secara spesifik class model akan mengandung fungsi kode yang membantu dalam segala proses yang berhubungan dengan basis data seperti memasukkan, mengubah, mendapatkan, dan menghapus data dalam sebuah basis data. View merupakan informasi yang disampaikan ke pengguna. Sebuah view biasanya berupa halaman web, tetapi dalam CodeIgniter, sebuah view juga bisa berupa sebuah fragmen halaman seperti header dan footer. View juga bisa berupa jenis halaman web yang lain. Controller merupakan sebuah perantara antara Model dan View dan semua sumber yang 
dibutuhkan untuk memproses permintaan HTTP dan dalam membuat halaman web.

CI merupakan kerangka kerja pembuatan program yang paling fleksibel, Program yang menggunakan CI hanya perlu menentukan titik awal dari pembuatan programnya yaitu bergerak dari controller.

\subsection{Cross Apache MySQL PHP PERL (XAMPP)}

XAMPP merupakan sebuah singkatan yang berarti Cross Platform, Apache, MySQL, PHP, dan Perl. Program ini merupakan salah satu paket instalasi perangkat lunak yang tersedia gratis dalam General Public License (GNU) dan bersifat open source.

XAMPP adalah aplikasi web server instan yang dibutuhkan untuk membangun aplikasi berbasis web dan mendukung banyak sistem operasi, XAMPP merupakan kompilasi dari beberapa program. Fungsinya adalah sebagai server yang berdiri sendiri (localhost), yang terdiri atas program Apache HTTP Server, basis data $M Y S Q L$, dan penerjemah bahasa yang ditulis dalam bahasa pemrograman PHP dan Perl. XAMPP merupakan web server yang mudah digunakan dan dapat melayani tampilan halaman web yang dinamis (Ediwiyono, 2007).

Dengan menginstal XAMPP, tidak perlu lagi menginstal aplikasi server satu persatu karena di dalam XAMPP sudah terdapat :

1. Apache 2.2.14 ( Ipv6 Enabled) + open SSL 0.9 .81

2. MySQL 5.1.41 + PBXT engine

3. PHP 5.3.1

4. PHPMyAdmin 3.2.4

5. Perl 5.10.1

6. Filezilla FTP Server 0.9.33. Mercury Mail Transport System 4.72

\subsection{Teknologi Barcode}

Barcode adalah kode-kode untuk angka dan huruf yang terdiri dari kombinasi bar (garis) dengan berbagai ketebalan sesuai dengan isi kodenya. Kode tersebut mewakili data atau informasi tertentu. Kode berbentuk batangan balok dan berwarna hitam putih ini mengandung satu kumpulan kombinasi yang berlainan ukuran yang disusun sedemikian rupa. Ruang putih di antara garis-garis hitam tersebut, juga merupakan bagian dari kode. Alat yang digunakan untuk membaca barcode adalah barcode reader.

Cara kerja Barcode reader adalah dengan mengkodekan kembali barcode dengan mendeteksi intensitas pantulan sinar yang diterima. Barcode reader memancarkan sinar sepanjang barcode, kemudian membaca sebuah garis, jika intensitas pantulannya kecil (karena berwarna hitam) dan jika intensitas pantulannya besar (karena berwarna putih). Barcode merupakan instrumen yang bekerja berdasarkan asas kerja digital, maka hanya ada 2 sinyal data yang dikenal dan bersifat boolean, yaitu 0 atau 1. Ada arus listrik atau tidak ada (dengan besaran tegangan tertentu, misalnya 5 volt dan 0 volt). Warna hitam mewakili bilangan 0 dan warna putih mewakili bilangan 1. Warna hitam akan menyerap cahaya yang dipancarkan oleh barcode reader, sedangkan warna putih akan memantulkan balik cahaya tersebut.

Keuntungan dari barcode adalah dapat mengumpulkan dan membaca suatu informasi dengan cepat dan akurat serta dapat menyimpannya didalam komputer.

\subsection{Standar Penomoran dan Klasifikasi Buku}

Menurut User Manual ISBN (2012), ISBN (International Standard Book Number) didefinisikan sebagai kode pengidentifikasian buku yang bersifat unik. Informasi tentang judul, penerbit, dan kelompok penerbit tercakup dalam ISBN. ISBN terdiri dari deretan angka 13 digit, sebagai pemberi identifikasi terhadap satu judul buku yang diterbitkan oleh penerbit. Oleh karena itu, satu nomor ISBN untuk satu buku akan berbeda dengan nomor ISBN untuk buku yang lain.

Penulisan ISBN mengikuti pola EAN, yaitu 13 digit nomor. Tiga digit nomor pertama adalah 978, jadi struktur penomorannya adalah ISBN - 978 -kode negara - kode penerbit kode buku - no identifikasi. Contoh : ISBN 978-602-8519-93-9. Angka pengenal produk terbitan buku dari EAN (Prefix identifier) $=978$, kode negara (group identifier) $=602$ (default), kode penerbit (publisher 
prefix) $=8519$, kode judul (title identifier) $=93$, dan angka pemeriksa (check digit) $=9$.

Dewey Decimal Classification atau yang disingkat DDC, didefinisikan sebagai Sistem Klasifikasi Persepuluhan Dewey atau biasa disebut Sistem Klasifikasi DDC. Sistem ini dikembangkan pertama kali oleh Melvill Dewey pada tahun 1873, berlatar belakang dari pemikiran bagaimana membuat sebuah sistem penggolongan koleksi di perpustakaan yang mudah dimengerti dan diterima secara universal di perpustakaan-perpustakaan lainnya. Sistem penggolongan koleksi didasarkan pada pembagian angka desimal di mana setiap angka mewakili subjek atau tema tertentu.

Ada sepuluh kelas utama dalam klasifikasi Dewey. Sepuluh kelas tersebut dibagi lagi menjadi 10 bagian, yang kemudian dapat dibagi lagi menjadi 10 bagian (e-DDC Edisi ke-23).

Sepuluh kelas utama tersebut adalah :

1. Klasifikasi DDC 000 (Komputer, Informasi dan Referensi umum)

2. Klasifikasi DDC 100 (Filsafat dan Psikologi)

3. Klasifikasi DDC 200 (agama)

4. Klasifikasi DDC 300 (Ilmu Sosial)

5. Klasifikasi DDC 400 (bahasa)

6. Klasifikasi DDC 500 (Sains dan Matematika)

7. Klasifikasi DDC 600 (Teknologi)

8. Klasifikasi DDC 700 (Kesenian dan Rekreasi)

9. Klasifikasi DDC 800 (Sastra)

10. Klasifikasi DDC 900 (Sejarah dan Geografi)

\section{PERANCANGAN SISTEM}

\subsection{Metode Penelitian}

Metode yang digunakan dalam penelitian ini adalah System Development Life Cycle (SDLC). Langkah-langkah penelitian meliputi tahap perencanaan, tahap analisa kebutuhan, tahap perancangan (perancangan perangkat keras dan perangkat lunak, perancangan data, dan perancangan basis data), tahap implementasi, tahap pengujian, dan tahap pemeliharaan.

\subsection{Analisa Kebutuhan}

Sistem Informasi Perpustakaan ini diharapkan dapat membantu dan menunjang kegiatan operasional perpustakaan, seperti pencatatan data buku dan data anggota, peminjaman dan pengembalian buku, serta pembuatan laporan. Adapun kebutuhan Sistem Informasi Perpustakaan ini dibagi menjadi dua, yaitu kebutuhan fungsional dan kebutuhan non-fungsional.

\subsubsection{Kebutuhan Fungsional}

Berikut ini adalah kebutuhan fungsional dari Sistem Informasi Perpustakaan :

1. Sistem dapat menyimpan dan mengelola data buku pustaka, data laporan kerja praktek, dan data laporan tugas akhir.

2. Sistem dapat menyimpan dan mengelola data anggota.

3. Sistem dapat menangani pengelolaan data pengguna sistem (user).

4. Sistem dapat menangani peminjaman, perpanjangan, dan pengembalian buku pustaka.

5. Sistem dapat memberikan informasi peminjaman dan pengembalian buku.

6. Sistem dapat memberikan informasi denda per tanggal tertentu.

7. Sistem dapat memberikan informasi buku yang tersedia kepada anggota perpustakaan.

8. Sistem dapat melihat status buku serta menangani transaksi peminjaman dan pengembalian buku dengan menggunakan barcode reader.

9. Sistem dapat memberikan laporan jumlah peminjaman dan pengembalian buku per bulan dalam setahun.

10. Sistem dapat memberikan laporan jumlah pengadaan dan pertambahan buku per bulan dalam setahun.

11. Sistem dapat memberikan laporan evaluasi perpustakaan yang meliputi jumlah peminjaman, jumlah pengembalian, jumlah anggota baru, jumlah buku pustaka baru, jumlah laporan kerja praktek baru, jumlah laporan tugas akhir baru, jumlah pengadaan buku dari fakultas, jurusan, dan mahasiswa / alumni, serta jumlah denda dalam sebulan dalam setahun. 
12. Sistem dapat menangani proses import excel yang meliputi data buku pustaka, data laporan kerja praktek, data laporan tugas akhir, dan data anggota perpustakaan.

13. Sistem dapat menangani proses penyesuaian jumlah buku (adjustment) dan memberikan laporan adjustment.

\subsubsection{Kebutuhan Non-Fungsional}

Berikut ini adalah kebutuhan nonfungsional dari Sistem Informasi Perpustakaan :

1. Sistem berbasis web.

2. Sistem memiliki antarmuka yang mudah digunakan oleh pengguna sistem (user friendly).

3. Laporan-laporan yang diberikan oleh sistem dapat di ubah menjadi bentuk Microsoft Office Excel.

\subsection{Perancangan Perangkat Lunak dan Perangkat Keras}

Perangkat lunak yang dibutuhkan untuk membuat sistem informasi perpustakaan ini adalah :

1. XAMPP (Basis Data MySQL, Web Server Apache)

2. Css Template

3. Notepad ++

Sedangkan, perangkat keras yang dibutuhkan adalah sebuah pc yang akan digunakan sebagai server lokal, dan sebuah barcode reader.

\subsection{Perancangan Data}

Perancangan data Sistem Informasi Perpustakaan Teknik Lingkungan adalah sebagai berikut :

1. Sistem ini memiliki beberapa aktor yang terlibat langsung dengan sistem informasi, yaitu Anggota dan User. Anggota adalah anggota perpustakaan, terdiri atas Mahasiswa, Dosen, dan Karyawan. User adalah pengelola sistem, yaitu Admin.

2. Proses utama yang ditangani oleh sistem informasi ini adalah pengelolaan data buku yang meliputi buku pustaka, laporan kerja praktek, dan laporan tugas akhir, pengelolaan data anggota, pengelolaan transaksi peminjaman, perpanjangan, dan pengembalian buku, pengelolaan laporan, seperti laporan pengadaan dan pertambahan buku, laporan peminjaman dan evaluasi perpustakaan, mengimport data dari file excel, serta melakukan adjustment buku.

Diagram Usecase Sistem Informasi Perpustakaan ditunjukkan oleh Gambar 2 berikut :

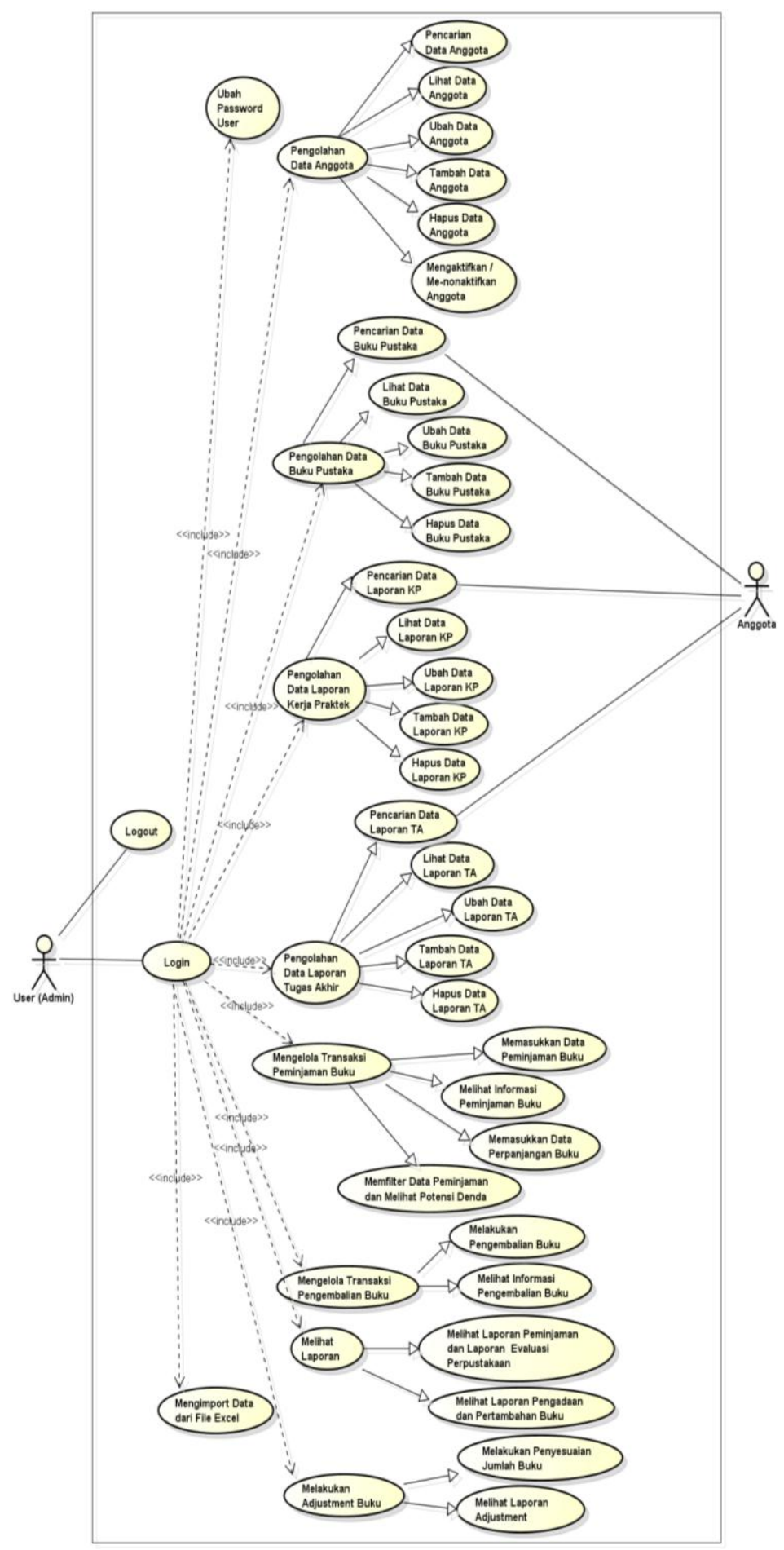

Gambar 2 Diagram Usecase 
Perancangan Data dari Sistem Informasi Perpustakaan Teknik Lingkungan akan digambarkan dengan diagram usecase. Masing-masing aktor terlibat usecase yang berbeda. Usecase-usecase yang ditangani oleh User (Admin) diantaranya adalah Ubah Password User, Pengolahan Data Anggota, Pengolahan Data Buku Pustaka, Pengolahan Data Laporan Kerja Praktek, Pengolahan Data Laporan Tugas Akhir, Mengelola Transaksi Peminjaman Buku, Mengelola Transaksi Pengembalian Buku, Melihat Laporan, Meng-import Data dari File Excel, dan Melakukan Adjustment Buku.

Usecase-usecase yang ditangani oleh Anggota (Mahasiswa, Dosen, dan Karyawan) diantaranya adalah Pencarian Data Buku Pustaka, Pencarian Data Laporan KP, dan Pencarian Data Laporan TA.

Diagram Kelas Sistem Informasi Perpustakaan ditunjukkan oleh Gambar 3 berikut :

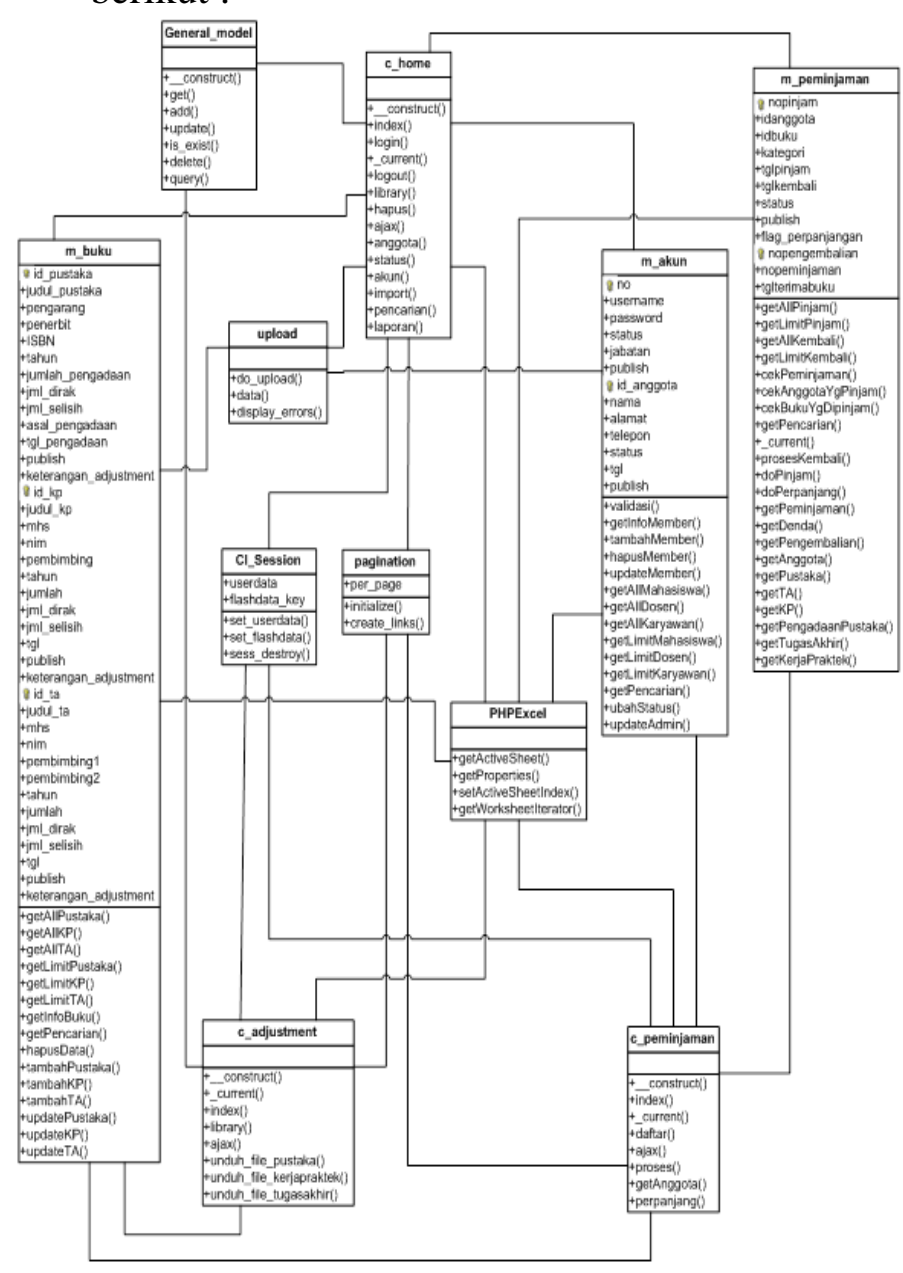

Gambar 3 Diagram Kelas
Diagram Sekuensial untuk usecase pencarian data buku pustaka oleh anggota ditunjukkan oleh Gambar 4 berikut :

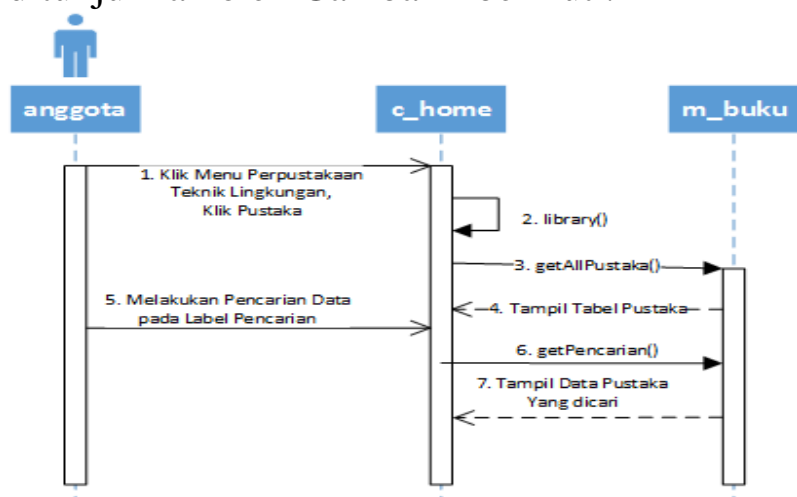

Gambar 4 Diagram Sekuensial Pencarian Data Buku Pustaka oleh Anggota

Diagram Sekuensial untuk usecase login ditunjukkan oleh Gambar 5 berikut :

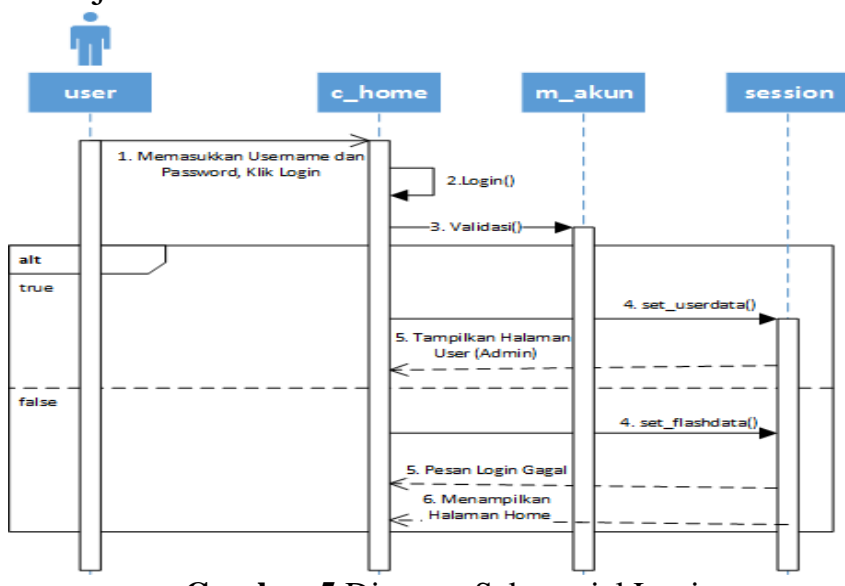

Gambar 5 Diagram Sekuensial Login

Diagram Sekuensial untuk usecase tambah data pustaka ditunjukkan oleh Gambar 6 berikut :

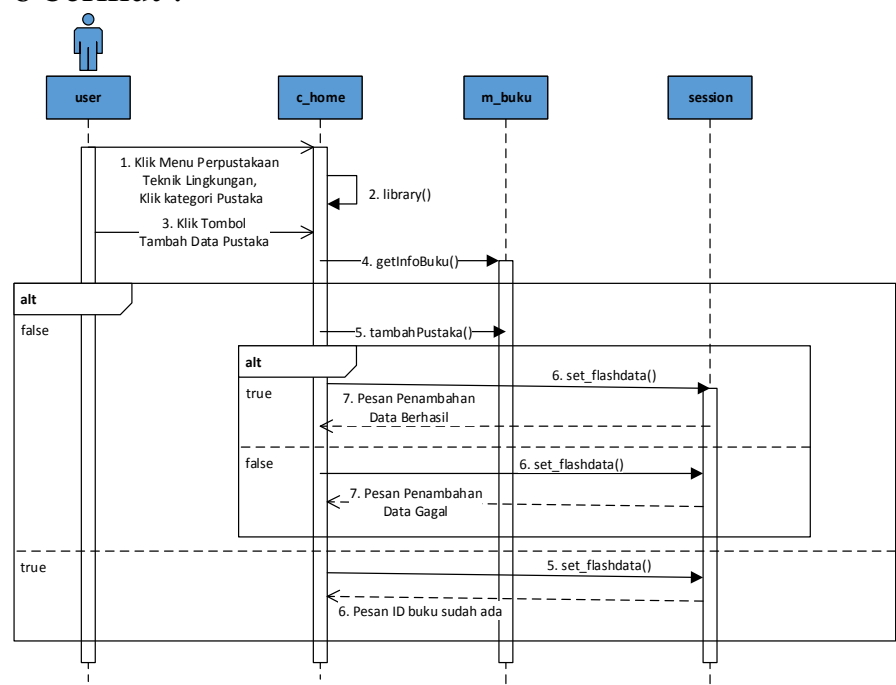

Gambar 6 Diagram Sekuensial Tambah Data Pustaka 
Diagram Sekuensial untuk usecase ubah data laporan KP ditunjukkan oleh Gambar 7 berikut :

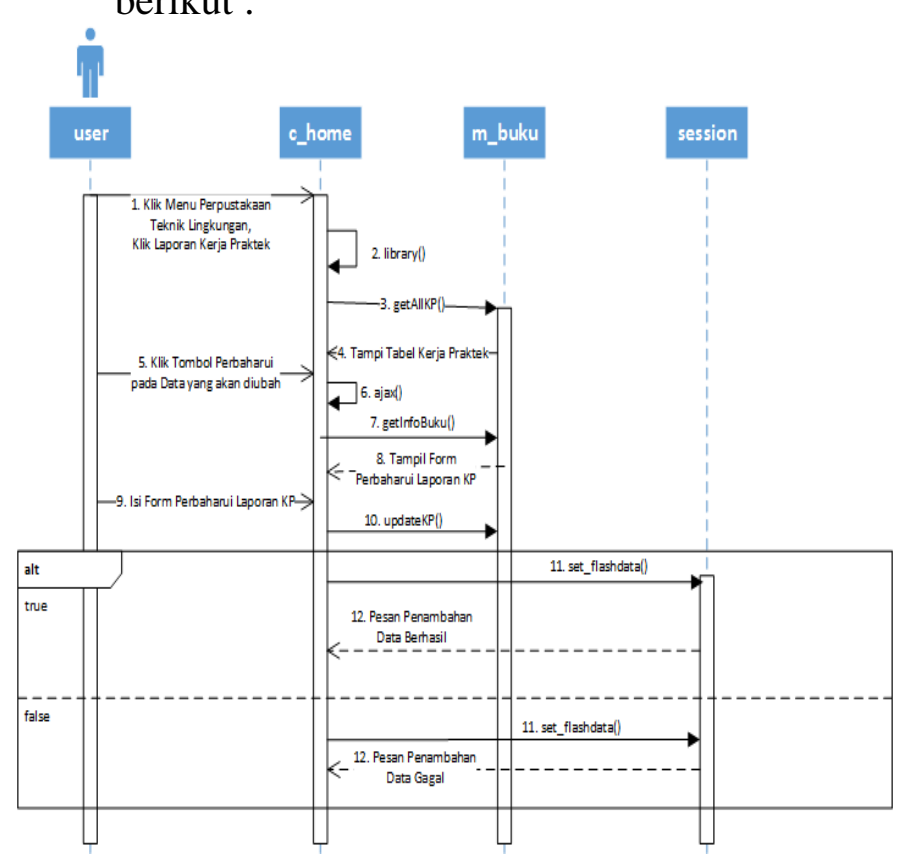

Gambar 7 Diagram Sekuensial Ubah Data Laporan KP

Diagram Sekuensial untuk usecase hapus data laporan ta ditunjukkan oleh Gambar 8 berikut :

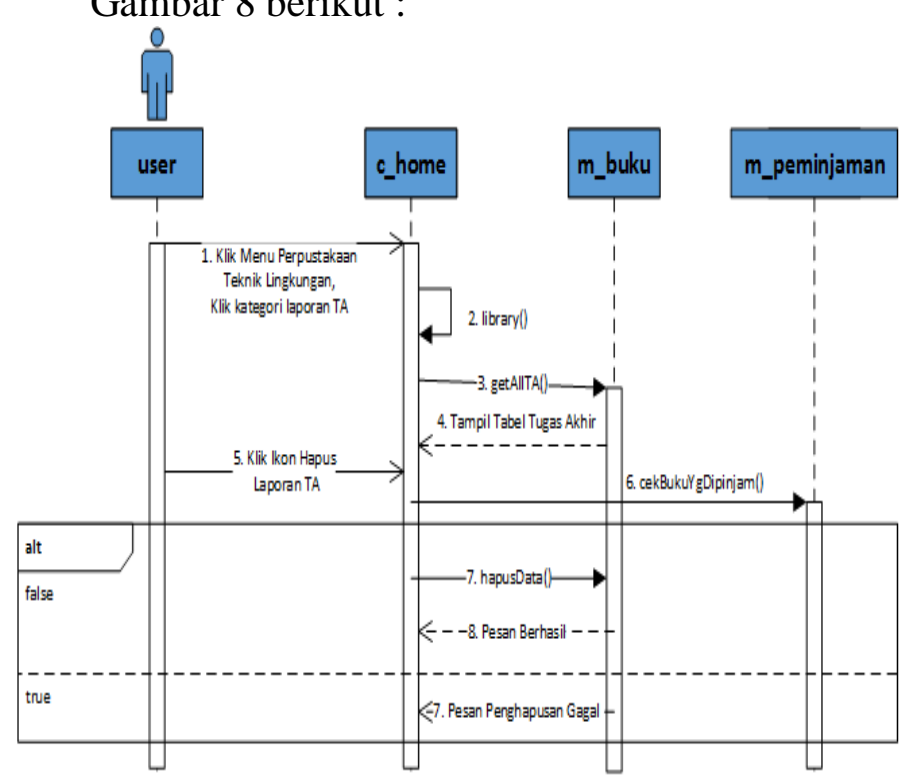

Gambar 8 Diagram Sekuensial Hapus Data Laporan TA

Diagram Sekuensial untuk usecase tambah data anggota ditunjukkan oleh Gambar 9 berikut :

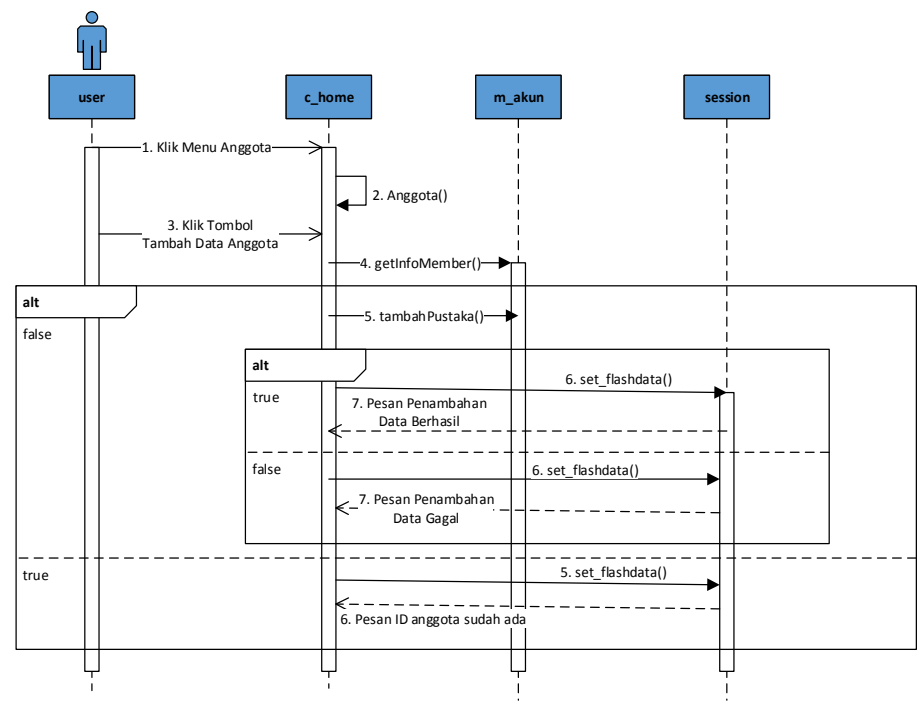

Gambar 9 Diagram Sekuensial Tambah Data Anggota

Diagram Sekuensial untuk usecase memasukkan data peminjaman buku ditunjukkan oleh Gambar 10 berikut :

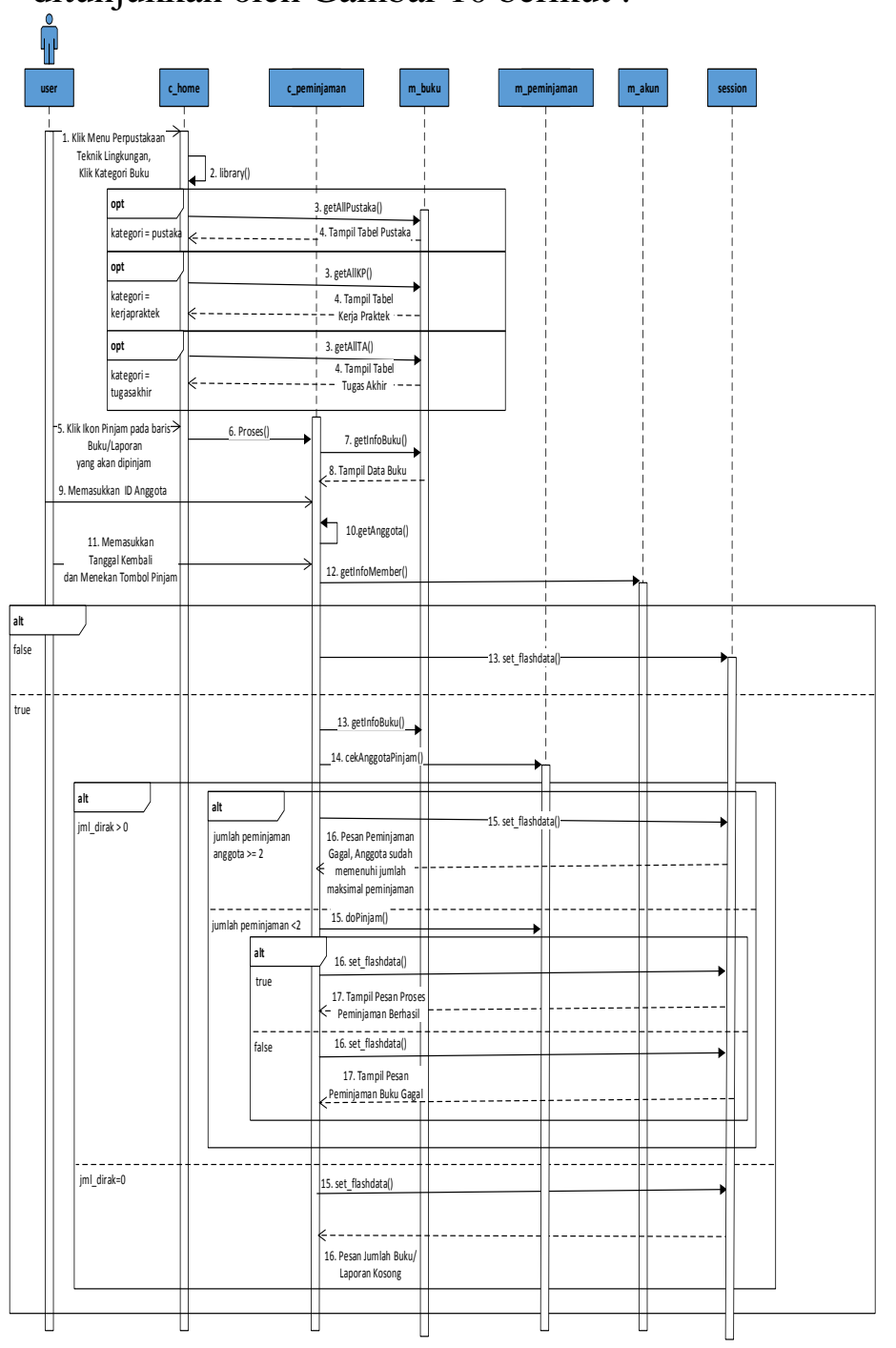

Gambar 10 Diagram Sekuensial Peminjaman 
Diagram Sekuensial untuk usecase pengembalian buku ditunjukkan oleh Gambar 11 berikut :

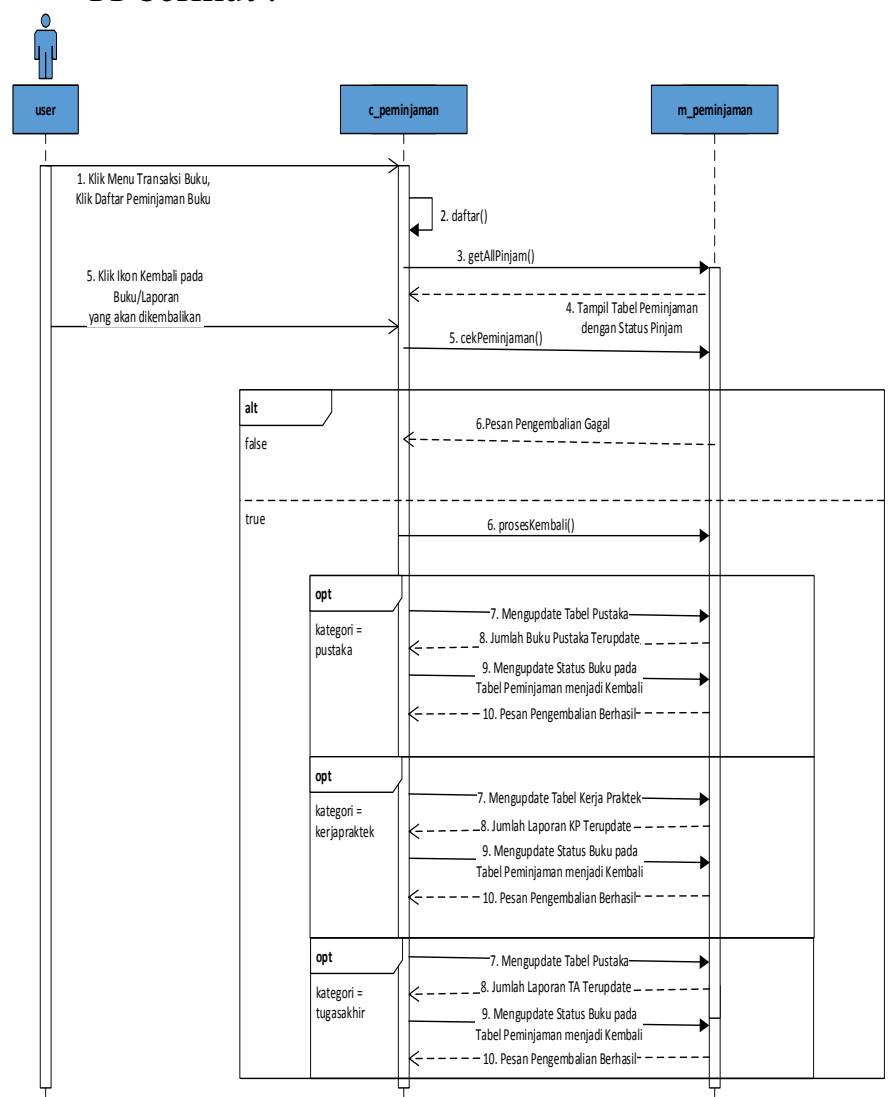

Gambar 11 Diagram Sekuensial Pengembalian

\subsection{Perancangan Basis Data}

Skema Basis Data Perpustakaan Teknik Lingkungan ditunjukkan pada gambar 12 berikut ini:

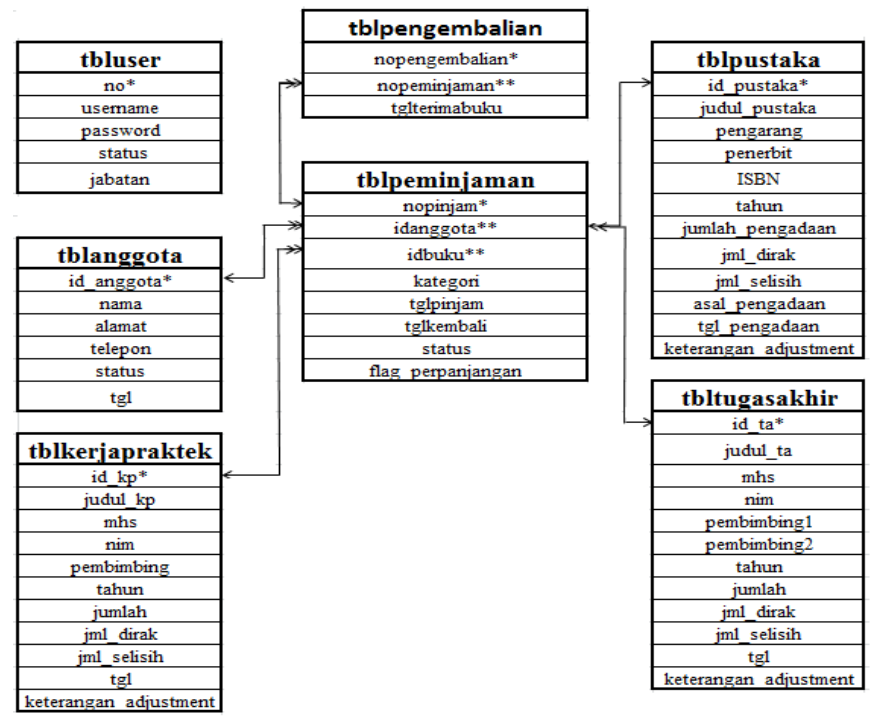

Gambar 12 Skema Basis Data Perpustakaan Teknik Lingkungan
Basis Data Perpustakaan Teknik Lingkungan terdiri dari 7 tabel, yaitu tabel user, tabel pustaka, tabel kerja praktek, tabel tugas akhir, tabel anggota, tabel peminjaman dan tabel pengembalian. Field yang bertanda * adalah kunci utama (primary key), dan yang bertanda ** adalah kunci referensi (foreign key).

\section{IMPLEMENTASI DAN PENGUJIAN SISTEM \\ 4.1 Implementasi Basis Data}

Implementasi merupakan tahap penerapan dari hasil perancangan yang telah dibuat sebelumnya. Implementasi bertujuan untuk menghasilkan sebuah sistem informasi yang sesuai dengan kebutuhan. Tahapan yang dilakukan adalah dengan mengimplementasikan basis data beserta tabel-tabel yang dibutuhkan oleh sistem.

Basis Data yang digunakan dalam Sistem Informasi Perpustakaan Teknik Lingkungan adalah basis data 'perpustakaanteknik lingkungan'. Basis data perpustakaan teknik lingkungan memiliki tujuh tabel, yaitu tbluser, tblanggota, tblpustaka, tblkerjapraktek, tbltugasakhir, tblpeminjaman, dan tblpengembalian. Setiap tabel memiliki kunci utama (primary key).

\subsection{Pengujian Sistem}

Metode yang digunakan untuk pengujian Sistem Informasi Perpustakaan Teknik Lingkungan adalah Black Box Testing, yaitu dengan memberikan masukan pada sistem dan melihat keluaran yang dihasilkan oleh sistem, dengan memperhatikan antarmuka sistem. Hasil yang diharapkan dari pengujian sistem adalah ketepatan sistem dalam mengelola masukan dan memberikan keluaran. Pengujian fungsi-fungsi sistem informasi perpustakaan dibagi menjadi dua pengujian untuk masingmasing aktor yaitu anggota (mahasiswa, dosen, dan karyawan) dan user (admin).

Pengujian fungsi-fungsi anggota ditunjukkan oleh Tabel 4.1 berikut : 
Tabel 4.1 Tabel Pengujian Fungsi-fungsi Anggota

\begin{tabular}{|c|c|c|c|}
\hline $\begin{array}{l}\text { Nama } \\
\text { Fungsi }\end{array}$ & $\begin{array}{l}\text { Bentuk } \\
\text { Pengujian }\end{array}$ & $\begin{array}{l}\text { Hasil Yang } \\
\text { Diharapkan }\end{array}$ & $\begin{array}{l}\text { Hasil } \\
\text { Pengujian }\end{array}$ \\
\hline $\begin{array}{l}\text { Penca- } \\
\text { rian data } \\
\text { buku } \\
\text { oleh } \\
\text { anggota }\end{array}$ & $\begin{array}{l}\text { Pencarian } \\
\text { data buku } \\
\text { dengan } \\
\text { mengguna- } \\
\text { kan kata } \\
\text { kunci }\end{array}$ & $\begin{array}{l}\text { Sistem } \\
\text { menampil- } \\
\text { kan data } \\
\text { buku } \\
\text { berdasarkan } \\
\text { kata kunci } \\
\text { yang } \\
\text { digunakan } \\
\text { dalam } \\
\text { pencarian }\end{array}$ & $\begin{array}{l}\text { Sistem } \\
\text { berhasil } \\
\text { menampil- } \\
\text { kan data } \\
\text { buku } \\
\text { berdasarkan } \\
\text { keterangan } \\
\text { yang dicari }\end{array}$ \\
\hline $\begin{array}{l}\text { Lihat } \\
\text { Ketera- } \\
\text { ngan } \\
\text { Buku }\end{array}$ & $\begin{array}{l}\text { Menekan } \\
\text { ikon } \\
\text { Selengkap- } \\
\text { nya }\end{array}$ & $\begin{array}{l}\text { Sistem } \\
\text { menampil- } \\
\text { kan form } \\
\text { keterangan } \\
\text { buku }\end{array}$ & $\begin{array}{l}\text { Sistem } \\
\text { berhasil } \\
\text { menampil- } \\
\text { kan form } \\
\text { keterangan } \\
\text { buku }\end{array}$ \\
\hline
\end{tabular}

Pengujian fungsi-fungsi user (admin ) ditunjukkan oleh Tabel 4.2 berikut :

Tabel 4.2 Tabel Pengujian Fungsi-fungsi User

\begin{tabular}{|c|c|c|c|}
\hline $\begin{array}{l}\text { Nama } \\
\text { Fungsi }\end{array}$ & $\begin{array}{l}\text { Bentuk } \\
\text { Pengujian }\end{array}$ & $\begin{array}{l}\text { Hasil Yang } \\
\text { Diharapkan }\end{array}$ & $\begin{array}{l}\text { Hasil } \\
\text { Pengujian }\end{array}$ \\
\hline Login & $\begin{array}{l}\text { a.User- } \\
\text { name dan } \\
\text { atau } \\
\text { Password } \\
\text { Invalid } \\
\\
\text { b.User- } \\
\text { name dan } \\
\text { Password } \\
\text { Valid }\end{array}$ & $\begin{array}{l}\text { a.Menampil- } \\
\text { kan pesan } \\
\text { bahwa } \\
\text { username dan } \\
\text { atau password } \\
\text { tidak sesuai } \\
\text { b.Sistem } \\
\text { menerima } \\
\text { akses login } \\
\text { dan } \\
\text { menampilkan } \\
\text { halaman } \\
\text { admin }\end{array}$ & $\begin{array}{l}\text { a.Validasi } \\
\text { tidak sah, } \\
\text { sistem } \\
\text { menampil- } \\
\text { kan pesan } \\
\text { bahwa } \\
\text { username } \\
\text { dan atau } \\
\text { password } \\
\text { tidak sesuai } \\
\text { b. Validasi } \\
\text { sah, sistem } \\
\text { menerima } \\
\text { akses login } \\
\text { dan } \\
\text { menampil- } \\
\text { kan halaman } \\
\text { admin }\end{array}$ \\
\hline Logout & $\begin{array}{l}\text { Memilih } \\
\text { menu } \\
\text { Logout }\end{array}$ & $\begin{array}{l}\text { Sistem akan } \\
\text { memutuskan } \\
\text { hak akses user } \\
\text { dan akan } \\
\text { menampilkan } \\
\text { kembali } \\
\text { halaman home }\end{array}$ & $\begin{array}{l}\text { sistem } \\
\text { berhasil } \\
\text { memutuskan } \\
\text { hak akses } \\
\text { user dan } \\
\text { kembali } \\
\text { menampil- } \\
\text { kan halaman } \\
\text { home }\end{array}$ \\
\hline
\end{tabular}

\begin{tabular}{|c|c|c|c|}
\hline $\begin{array}{l}\text { Per- } \\
\text { baharui } \\
\text { Akun } \\
\text { User }\end{array}$ & $\begin{array}{l}\text { a.Menekan } \\
\text { menu } \\
\text { Ubah } \\
\text { Akun } \\
\text { b.Meng- } \\
\text { ubah } \\
\text { password }\end{array}$ & $\begin{array}{l}\text { a.Sistem } \\
\text { menampilkan } \\
\text { form } \\
\text { Perbaharui } \\
\text { Akun User } \\
\text { b.Sistem } \\
\text { menampilkan } \\
\text { pesan bahwa } \\
\text { pengubahan } \\
\text { password } \\
\text { berhasil }\end{array}$ & $\begin{array}{l}\text { a.Sistem } \\
\text { berhasil } \\
\text { menampil- } \\
\text { kan form } \\
\text { Perbaharui } \\
\text { Akun User } \\
\\
\text { b.Sistem } \\
\text { berhasil } \\
\text { menampil- } \\
\text { kan pesan } \\
\text { bahwa } \\
\text { pengubahan } \\
\text { password } \\
\text { berhasil }\end{array}$ \\
\hline $\begin{array}{l}\text { Tam- } \\
\text { bah } \\
\text { data } \\
\text { buku } \\
\text { pustaka }\end{array}$ & $\begin{array}{l}\text { a.Menekan } \\
\text { Tombol } \\
\text { Tambah } \\
\text { Data } \\
\text { Pustaka } \\
\text { b.Menam- } \\
\text { bah data } \\
\text { buku } \\
\text { pustaka } \\
\text { baru } \\
\text { c.Menam- } \\
\text { bah data } \\
\text { buku } \\
\text { pustaka } \\
\text { yang sudah } \\
\text { ada }\end{array}$ & $\begin{array}{l}\text { a.Menampil- } \\
\text { kan form } \\
\text { Tambah Data } \\
\text { Pustaka } \\
\text { b.Sistem } \\
\text { menampilkan } \\
\text { pesan bahwa } \\
\text { penambahan } \\
\text { data buku } \\
\text { pustaka } \\
\text { berhasil } \\
\text { c.Sistem } \\
\text { menampilkan } \\
\text { pesan bahwa } \\
\text { penambahan } \\
\text { data buku } \\
\text { gagal, id buku } \\
\text { telah ada }\end{array}$ & $\begin{array}{l}\text { a.Sistem } \\
\text { berhasil } \\
\text { menampil- } \\
\text { kan form } \\
\text { Tambah } \\
\text { Data Pustaka } \\
\text { b.Sistem } \\
\text { berhasil } \\
\text { menampil- } \\
\text { kan pesan } \\
\text { bahwa } \\
\text { penambahan } \\
\text { data buku } \\
\text { pustaka } \\
\text { berhasil } \\
\text { c.Sistem } \\
\text { berhasil } \\
\text { menampil- } \\
\text { kan pesan } \\
\text { bahwa } \\
\text { penambahan } \\
\text { data buku } \\
\text { gagal, id } \\
\text { buku telah } \\
\text { ada }\end{array}$ \\
\hline $\begin{array}{l}\text { Cari } \\
\text { data } \\
\text { buku } \\
\text { pustaka }\end{array}$ & $\begin{array}{l}\text { a. } \\
\text { Pencarian } \\
\text { data buku } \\
\text { dengan } \\
\text { mengguna- } \\
\text { kan kata } \\
\text { kunci } \\
\text { b. } \\
\text { Pencarian } \\
\text { data buku } \\
\text { mengguna- } \\
\text { kan } \\
\text { barcode } \\
\text { reader }\end{array}$ & $\begin{array}{l}\text { a.Sistem } \\
\text { menampilkan } \\
\text { data buku } \\
\text { berdasarkan } \\
\text { kata kunci } \\
\text { yang } \\
\text { digunakan } \\
\text { dalam } \\
\text { pencarian } \\
\text { b.Barcode } \\
\text { reader } \\
\text { membaca dan } \\
\text { mendekode- } \\
\text { kan ISBN } \\
\text { buku }\end{array}$ & $\begin{array}{l}\text { a. Sistem } \\
\text { berhasil } \\
\text { menampil- } \\
\text { kan data } \\
\text { buku } \\
\text { berdasarkan } \\
\text { kata kunci } \\
\text { yang } \\
\text { digunakan } \\
\text { dalam } \\
\text { pencarian } \\
\text { b. Barcode } \\
\text { reader } \\
\text { berhasil } \\
\text { membaca } \\
\text { dan } \\
\text { mendekode- }\end{array}$ \\
\hline
\end{tabular}




\begin{tabular}{|c|c|c|c|}
\hline & & & $\begin{array}{l}\text { kan ISBN } \\
\text { buku }\end{array}$ \\
\hline $\begin{array}{l}\text { Lihat } \\
\text { data } \\
\text { laporan } \\
\text { kerja } \\
\text { praktek }\end{array}$ & $\begin{array}{l}\text { Menekan } \\
\text { ikon } \\
\text { Selengkap- } \\
\text { nya }\end{array}$ & $\begin{array}{l}\text { Menampilkan } \\
\text { form } \\
\text { keterangan } \\
\text { laporan kerja } \\
\text { praktek }\end{array}$ & $\begin{array}{l}\text { Sistem } \\
\text { berhasil } \\
\text { menampil- } \\
\text { kan form } \\
\text { keterangan } \\
\text { laporan kerja } \\
\text { praktek }\end{array}$ \\
\hline $\begin{array}{l}\text { Ubah } \\
\text { data } \\
\text { laporan } \\
\text { kerja } \\
\text { praktek }\end{array}$ & $\begin{array}{l}\text { a.Menekan } \\
\text { ikon } \\
\text { Perbaharui } \\
\text { Laporan } \\
\text { KP } \\
\text { b.Menekan } \\
\text { Tombol } \\
\text { Perbaharui }\end{array}$ & $\begin{array}{l}\text { a.Menampil- } \\
\text { kan form } \\
\text { Perbaharui } \\
\text { Laporan KP } \\
\text { yang berisi } \\
\text { data laporan } \\
\text { kerja praktek } \\
\text { yang akan } \\
\text { diubah } \\
\text { b.Sistem } \\
\text { menampilkan } \\
\text { pesan bahwa } \\
\text { pengubahan } \\
\text { data laporan } \\
\text { kerja praktek } \\
\text { berhasil }\end{array}$ & $\begin{array}{l}\text { a.Sistem } \\
\text { berhasil } \\
\text { menampil- } \\
\text { kan form } \\
\text { Perbaharui } \\
\text { Laporan KP } \\
\text { yang berisi } \\
\text { data laporan } \\
\text { kerja praktek } \\
\text { yang akan } \\
\text { diubah } \\
\text { b.Sistem } \\
\text { berhasil } \\
\text { menampil- } \\
\text { kan pesan } \\
\text { bahwa } \\
\text { pengubahan } \\
\text { data laporan } \\
\text { kerja praktek } \\
\text { berhasil }\end{array}$ \\
\hline $\begin{array}{l}\text { Pinjam } \\
\text { laporan } \\
\text { tugas } \\
\text { akhir }\end{array}$ & $\begin{array}{l}\text { a.Menekan } \\
\text { ikon } \\
\text { Pinjam } \\
\text { Laporan } \\
\text { TA } \\
\text { b.Mema- } \\
\text { sukkan } \\
\text { data } \\
\text { peminja- } \\
\text { man } \\
\text { anggota } \\
\text { yang aktif } \\
\text { dan } \\
\text { statusnya } \\
\text { dosen/ } \\
\text { karyawan } \\
\text { c.Mema- } \\
\text { sukkan } \\
\text { data } \\
\text { peminja- } \\
\text { man } \\
\text { anggota } \\
\text { yang non- } \\
\text { aktif dan } \\
\text { atau } \\
\text { statusnya } \\
\text { mahasiswa }\end{array}$ & $\begin{array}{l}\text { a.Menampil- } \\
\text { kan form } \\
\text { peminjaman } \\
\text { laporan tugas } \\
\text { akhir } \\
\text { b.Mengecek } \\
\text { status anggota } \\
\text { dan } \\
\text { menampilkan } \\
\text { nama anggota } \\
\text { c.Mengecek } \\
\text { status anggota } \\
\text { dan } \\
\text { menampilkan } \\
\text { pesan bahwa } \\
\text { id tidak } \\
\text { ditemukan. } \\
\text { d.Menampil- } \\
\text { kan pesan } \\
\text { bahwa } \\
\text { peminjaman } \\
\text { gagal, karena } \\
\text { anggota telah } \\
\text { memenuhi } \\
\text { jumlah } \\
\text { maksimal } \\
\text { peminjaman }\end{array}$ & $\begin{array}{l}\text { a.Sistem } \\
\text { berhasil } \\
\text { menampil- } \\
\text { kan form } \\
\text { peminjaman } \\
\text { laporan } \\
\text { tugas akhir } \\
\text { b.Sistem } \\
\text { berhasil } \\
\text { mengecek } \\
\text { status } \\
\text { anggota dan } \\
\text { menampil- } \\
\text { kan nama } \\
\text { anggota } \\
\text { c.Sistem } \\
\text { berhasil } \\
\text { mengecek } \\
\text { status } \\
\text { anggota dan } \\
\text { menampil- } \\
\text { kan pesan } \\
\text { bahwa id } \\
\text { tidak } \\
\text { ditemukan } \\
\text { d.Sistem } \\
\text { berhasil }\end{array}$ \\
\hline
\end{tabular}

\begin{tabular}{|c|c|c|c|}
\hline & $\begin{array}{l}\text { d.Anggota } \\
\text { meminjam } \\
\text { lebih dari } 2 \\
\text { buku }\end{array}$ & buku & $\begin{array}{l}\text { menampil- } \\
\text { kan pesan } \\
\text { bahwa } \\
\text { peminjaman } \\
\text { gagal, } \\
\text { karena } \\
\text { anggota } \\
\text { telah } \\
\text { memenuhi } \\
\text { jumlah } \\
\text { maksimal } \\
\text { peminjaman } \\
\text { buku }\end{array}$ \\
\hline $\begin{array}{l}\text { Hapus } \\
\text { data } \\
\text { laporan } \\
\text { tugas } \\
\text { akhir }\end{array}$ & $\begin{array}{l}\text { a.Mengha- } \\
\text { pus } \\
\text { laporan } \\
\text { yang tidak } \\
\text { dipinjam } \\
\text { b.Mengha- } \\
\text { pus } \\
\text { laporan } \\
\text { yang masih } \\
\text { dipinjam }\end{array}$ & $\begin{array}{l}\text { a.Melakukan } \\
\text { pengecekan } \\
\text { data } \\
\text { peminjaman } \\
\text { laporan, dan } \\
\text { menampilkan } \\
\text { pesan bahwa } \\
\text { penghapusan } \\
\text { data laporan } \\
\text { berhasil } \\
\text { b.Melakukan } \\
\text { pengecekan } \\
\text { data } \\
\text { peminjaman } \\
\text { laporan, dan } \\
\text { menampilkan } \\
\text { pesan bahwa } \\
\text { penghapusan } \\
\text { data laporan } \\
\text { gagal, } \\
\text { dikarenakan } \\
\text { laporan masih } \\
\text { dipinjam }\end{array}$ & $\begin{array}{l}\text { a.Sistem } \\
\text { berhasil } \\
\text { melakukan } \\
\text { pengecekan } \\
\text { data } \\
\text { peminjaman } \\
\text { laporan, dan } \\
\text { menampil- } \\
\text { kan pesan } \\
\text { bahwa } \\
\text { penghapusan } \\
\text { data laporan } \\
\text { berhasil } \\
\\
\text { b.Sistem } \\
\text { berhasil } \\
\text { melakukan } \\
\text { pengecekan } \\
\text { data } \\
\text { peminjaman } \\
\text { laporan, dan } \\
\text { menampil- } \\
\text { kan pesan } \\
\text { bahwa } \\
\text { penghapusan } \\
\text { data laporan } \\
\text { gagal, } \\
\text { dikarenakan } \\
\text { laporan } \\
\text { masih } \\
\text { dipinjam }\end{array}$ \\
\hline $\begin{array}{l}\text { Tam- } \\
\text { bah } \\
\text { data } \\
\text { anggota }\end{array}$ & $\begin{array}{l}\text { a.Menekan } \\
\text { Tombol } \\
\text { Tambah } \\
\text { Data } \\
\text { Anggota } \\
\text { b.Menam- } \\
\text { bah data } \\
\text { anggota } \\
\text { baru } \\
\text { c.Menam- } \\
\text { bah data } \\
\text { anggota } \\
\text { yang sudah } \\
\text { ada }\end{array}$ & $\begin{array}{l}\text { a.Menampil- } \\
\text { kan form } \\
\text { Tambah } \\
\text { Anggota } \\
\text { b.Menampil- } \\
\text { kan pesan } \\
\text { bahwa } \\
\text { penambahan } \\
\text { data anggota } \\
\text { berhasil. } \\
\text { c.Menampil- } \\
\text { kan pesan } \\
\text { bahwa } \\
\text { penambahan }\end{array}$ & $\begin{array}{l}\text { a.Sistem } \\
\text { berhasil } \\
\text { menampil- } \\
\text { kan form } \\
\text { Tambah } \\
\text { Anggota } \\
\text { b.Sistem } \\
\text { berhasil } \\
\text { menampil- } \\
\text { kan pesan } \\
\text { bahwa } \\
\text { penambahan } \\
\text { data anggota } \\
\text { berhasil } \\
\text { c.Sistem }\end{array}$ \\
\hline
\end{tabular}




\begin{tabular}{|c|c|c|c|}
\hline & & $\begin{array}{l}\text { data anggota } \\
\text { gagal, } \\
\text { dikarenakan id } \\
\text { anggota telah } \\
\text { ada }\end{array}$ & $\begin{array}{l}\text { berhasil } \\
\text { menampil- } \\
\text { kan pesan } \\
\text { bahwa } \\
\text { penambahan } \\
\text { data anggota } \\
\text { gagal, } \\
\text { dikarenakan } \\
\text { id anggota } \\
\text { telah ada }\end{array}$ \\
\hline $\begin{array}{l}\text { Aktif- } \\
\text { kan/ } \\
\text { non- } \\
\text { aktif- } \\
\text { kan } \\
\text { anggota }\end{array}$ & $\begin{array}{l}\text { a.Menon- } \\
\text { aktifkan } \\
\text { anggota } \\
\text { yang tidak } \\
\text { sedang } \\
\text { meminjam } \\
\text { b.Menon- } \\
\text { aktifkan } \\
\text { Anggota } \\
\text { yang } \\
\text { sedang } \\
\text { meminjam }\end{array}$ & $\begin{array}{l}\text { a.Sistem } \\
\text { melakukan } \\
\text { pengecekan } \\
\text { data } \\
\text { peminjaman, } \\
\text { dan penon- } \\
\text { aktifkan } \\
\text { anggota yang } \\
\text { tidak sedang } \\
\text { meminjam. } \\
\text { buku/laporan } \\
\text { b.Sistem } \\
\text { melakukan } \\
\text { pengecekan } \\
\text { data } \\
\text { peminjaman, } \\
\text { dan } \\
\text { menampilkan } \\
\text { pesan bahwa } \\
\text { penon-aktifan } \\
\text { anggota gagal, } \\
\text { dikarenakan } \\
\text { anggota } \\
\text { sedang } \\
\text { melakukan } \\
\text { peminjaman }\end{array}$ & $\begin{array}{l}\text { a.Sistem } \\
\text { berhasil } \\
\text { menonaktif- } \\
\text { kan anggota } \\
\text { yang tidak } \\
\text { sedang } \\
\text { melakukan } \\
\text { peminjaman } \\
\text { b.Sistem } \\
\text { berhasil } \\
\text { menampil- } \\
\text { kan pesan } \\
\text { bahwa } \\
\text { penon- } \\
\text { aktifan } \\
\text { anggota } \\
\text { gagal, } \\
\text { dikarenakan } \\
\text { anggota } \\
\text { sedang } \\
\text { melakukan } \\
\text { peminjaman }\end{array}$ \\
\hline $\begin{array}{l}\text { Lihat } \\
\text { data } \\
\text { pemin- } \\
\text { jaman }\end{array}$ & $\begin{array}{l}\text { Menekan } \\
\text { ikon lihat } \\
\text { keterangan } \\
\text { peminja- } \\
\text { man }\end{array}$ & $\begin{array}{l}\text { Menampilkan } \\
\text { form } \\
\text { keterangan } \\
\text { peminjaman }\end{array}$ & $\begin{array}{l}\text { Sistem } \\
\text { berhasil } \\
\text { menampil- } \\
\text { kan form } \\
\text { keterangan } \\
\text { peminjaman }\end{array}$ \\
\hline $\begin{array}{l}\text { Filter } \\
\text { data } \\
\text { pemin- } \\
\text { jaman } \\
\text { buku }\end{array}$ & $\begin{array}{l}\text { Memasuk- } \\
\text { kan range } \\
\text { waktu } \\
\text { peminja- } \\
\text { man }\end{array}$ & $\begin{array}{l}\text { Menampilkan } \\
\text { data } \\
\text { peminjaman } \\
\text { buku pada } \\
\text { range waktu } \\
\text { tertentu }\end{array}$ & $\begin{array}{l}\text { Sistem } \\
\text { berhasil } \\
\text { menampil- } \\
\text { kan data } \\
\text { peminjaman } \\
\text { buku pada } \\
\text { range waktu } \\
\text { yang difilter }\end{array}$ \\
\hline $\begin{array}{l}\text { Lihat } \\
\text { potensi } \\
\text { denda }\end{array}$ & $\begin{array}{l}\text { Memasuk- } \\
\text { kan range } \\
\text { waktu } \\
\text { peminja- } \\
\text { man, dan } \\
\text { memilih } \\
\text { checkbox } \\
\text { potensi } \\
\text { denda }\end{array}$ & $\begin{array}{l}\text { Menampilkan } \\
\text { data } \\
\text { peminjaman } \\
\text { buku yang } \\
\text { berpotensi } \\
\text { denda pada } \\
\text { range waktu } \\
\text { tertentu }\end{array}$ & $\begin{array}{l}\text { Sistem } \\
\text { berhasil } \\
\text { menampil- } \\
\text { kan data } \\
\text { peminjaman } \\
\text { buku yang } \\
\text { berpotensi } \\
\text { denda pada } \\
\text { range waktu }\end{array}$ \\
\hline
\end{tabular}

\begin{tabular}{|c|c|c|c|}
\hline & & & tertentu \\
\hline $\begin{array}{l}\text { Perpan- } \\
\text { jangan } \\
\text { buku }\end{array}$ & $\begin{array}{l}\text { a.Menekan } \\
\text { ikon } \\
\text { perpanja- } \\
\text { ngan buku } \\
\text { b.Melaku- } \\
\text { kan } \\
\text { perpanja- } \\
\text { ngan lebih } \\
\text { dari } 2 \text { kali }\end{array}$ & $\begin{array}{l}\text { a.Menampil- } \\
\text { kan form } \\
\text { perpanjangan } \\
\text { peminjaman } \\
\text { b.Menampil- } \\
\text { kan pesan } \\
\text { bahwa proses } \\
\text { perpanjangan } \\
\text { gagal, } \\
\text { dikarenakan } \\
\text { perpanjangan } \\
\text { maksimal } \\
\text { sebanyak } 2 \\
\text { kali }\end{array}$ & $\begin{array}{l}\text { a.Sistem } \\
\text { berhasil } \\
\text { menampil- } \\
\text { kan form } \\
\text { perpanja- } \\
\text { ngan } \\
\text { peminjaman } \\
\text { b.Sistem } \\
\text { berhasil } \\
\text { menampil- } \\
\text { kan pesan } \\
\text { bahwa } \\
\text { proses } \\
\text { perpanja- } \\
\text { ngan gagal, } \\
\text { dikarenakan } \\
\text { perpanja- } \\
\text { ngan } \\
\text { maksimal } \\
\text { sebanyak } 2 \\
\text { kali }\end{array}$ \\
\hline $\begin{array}{l}\text { Penge- } \\
\text { mbali- } \\
\text { an } \\
\text { buku }\end{array}$ & $\begin{array}{l}\text { Menekan } \\
\text { tombol } \\
\text { pengem- } \\
\text { balian } \\
\text { buku }\end{array}$ & $\begin{array}{l}\text { Mengubah } \\
\text { status buku } \\
\text { yang dipinjam } \\
\text { menjadi } \\
\text { kembali }\end{array}$ & $\begin{array}{l}\text { Sistem } \\
\text { berhasil } \\
\text { mengubah } \\
\text { status buku } \\
\text { pinjam } \\
\text { menjadi } \\
\text { kembali }\end{array}$ \\
\hline $\begin{array}{l}\text { Lihat } \\
\text { data } \\
\text { penge- } \\
\text { mbali- } \\
\text { an } \\
\text { buku }\end{array}$ & $\begin{array}{l}\text { Menekan } \\
\text { ikon lihat } \\
\text { keterangan } \\
\text { pengem- } \\
\text { balian }\end{array}$ & $\begin{array}{l}\text { Menampilkan } \\
\text { daftar } \\
\text { pengembalian } \\
\text { buku }\end{array}$ & $\begin{array}{l}\text { Sistem } \\
\text { berhasil } \\
\text { menampil- } \\
\text { kan daftar } \\
\text { pengem- } \\
\text { balian buku }\end{array}$ \\
\hline $\begin{array}{l}\text { Lihat } \\
\text { Lapo- } \\
\text { ran } \\
\text { Pemin- } \\
\text { jaman } \\
\text { buku } \\
\text { pustaka }\end{array}$ & $\begin{array}{l}\text { Memilih } \\
\text { tahun } \\
\text { laporan, } \\
\text { kategori } \\
\text { laporan } \\
\text { peminja- } \\
\text { man buku } \\
\text { pustaka, } \\
\text { dan bentuk } \\
\text { tabel }\end{array}$ & $\begin{array}{l}\text { Menampilkan } \\
\text { tabel laporan } \\
\text { jumlah } \\
\text { peminjaman } \\
\text { dan } \\
\text { pengembalian } \\
\text { buku pustaka } \\
\text { dalam setahun, } \\
\text { sesuai tahun } \\
\text { yang dipilih }\end{array}$ & $\begin{array}{l}\text { Sistem } \\
\text { berhasil } \\
\text { menampil- } \\
\text { kan tabel } \\
\text { laporan } \\
\text { jumlah } \\
\text { peminjaman } \\
\text { dan pengem- } \\
\text { balian buku } \\
\text { pustaka } \\
\text { dalam } \\
\text { setahun, } \\
\text { sesuai tahun } \\
\text { yang dipilih }\end{array}$ \\
\hline $\begin{array}{l}\text { Lihat } \\
\text { laporan } \\
\text { evalu- } \\
\text { asi } \\
\text { perpus- } \\
\text { takaan }\end{array}$ & $\begin{array}{l}\text { Memilih } \\
\text { tahun } \\
\text { laporan, } \\
\text { kategori } \\
\text { laporan } \\
\text { evaluasi } \\
\text { perpusta- } \\
\text { kaan, dan } \\
\text { bentuk } \\
\text { tabel }\end{array}$ & $\begin{array}{l}\text { Menampilkan } \\
\text { tabel laporan } \\
\text { evaluasi } \\
\text { perpustakaan } \\
\text { dalam setahun, } \\
\text { sesuai tahun } \\
\text { yang dipilih }\end{array}$ & $\begin{array}{l}\text { Sistem } \\
\text { berhasil } \\
\text { menampil- } \\
\text { kan tabel } \\
\text { laporan } \\
\text { evaluasi } \\
\text { perpustakaan } \\
\text { dalam } \\
\text { setahun, } \\
\text { sesuai tahun }\end{array}$ \\
\hline
\end{tabular}




\begin{tabular}{|c|c|c|c|}
\hline & & & yang dipilih \\
\hline $\begin{array}{l}\text { Lihat } \\
\text { laporan } \\
\text { penga- } \\
\text { daan } \\
\text { buku } \\
\text { pustaka }\end{array}$ & $\begin{array}{l}\text { Memilih } \\
\text { tahun } \\
\text { laporan, } \\
\text { kategori } \\
\text { laporan } \\
\text { pengadaan } \\
\text { buku } \\
\text { pustaka, } \\
\text { dan bentuk } \\
\text { tabel }\end{array}$ & $\begin{array}{l}\text { Menampilkan } \\
\text { tabel laporan } \\
\text { pengadaan } \\
\text { buku pustaka } \\
\text { dalam setahun, } \\
\text { sesuai tahun } \\
\text { yang dipilih }\end{array}$ & $\begin{array}{l}\text { Sistem } \\
\text { berhasil } \\
\text { menampil- } \\
\text { kan tabel } \\
\text { laporan } \\
\text { pengadaan } \\
\text { buku } \\
\text { pustaka } \\
\text { dalam } \\
\text { setahun, } \\
\text { sesuai tahun } \\
\text { yang dipilih }\end{array}$ \\
\hline $\begin{array}{l}\text { Unduh } \\
\text { laporan } \\
\text { penga- } \\
\text { daan } \\
\text { buku } \\
\text { pustaka }\end{array}$ & $\begin{array}{l}\text { Memilih } \\
\text { tahun } \\
\text { laporan, } \\
\text { kategori } \\
\text { laporan } \\
\text { pengadaan } \\
\text { buku } \\
\text { pustaka, } \\
\text { dan bentuk } \\
\text { excel }\end{array}$ & $\begin{array}{l}\text { Sistem akan } \\
\text { mengunduh } \\
\text { laporan } \\
\text { pengadaan } \\
\text { buku pustaka } \\
\text { dalam bentuk } \\
\text { dokumen } \\
\text { microsoft } \\
\text { office excel, } \\
\text { sesuai tahun } \\
\text { yang dipilih }\end{array}$ & $\begin{array}{l}\text { Sistem } \\
\text { berhasil } \\
\text { mengunduh } \\
\text { laporan } \\
\text { pengadaan } \\
\text { buku } \\
\text { pustaka } \\
\text { dalam } \\
\text { bentuk } \\
\text { dokumen } \\
\text { excel, sesuai } \\
\text { dengan } \\
\text { tahun yang } \\
\text { dipilih }\end{array}$ \\
\hline $\begin{array}{l}\text { Import } \\
\text { data }\end{array}$ & $\begin{array}{l}\text { Memilih } \\
\text { data yang } \\
\text { akan } \\
\text { diimport } \\
\text { (data buku } \\
\text { pustaka / } \\
\text { data } \\
\text { laporan KP } \\
\text { / data } \\
\text { laporan TA } \\
\text { / data } \\
\text { anggota) }\end{array}$ & $\begin{array}{l}\text { Menampilkan } \\
\text { pesan bahwa } \\
\text { proses import } \\
\text { berhasil }\end{array}$ & $\begin{array}{l}\text { Sistem } \\
\text { berhasil } \\
\text { menampil- } \\
\text { kan pesan } \\
\text { bahwa } \\
\text { proses } \\
\text { import } \\
\text { berhasil }\end{array}$ \\
\hline $\begin{array}{l}\text { Adjust } \\
\text { ment } \\
\text { pustaka }\end{array}$ & $\begin{array}{l}\text { a.Menekan } \\
\text { ikon } \\
\text { adjustment } \\
\text { pustaka } \\
\text { b.Menekan } \\
\text { tombol } \\
\text { simpan }\end{array}$ & $\begin{array}{l}\text { a.Menampil- } \\
\text { kan form } \\
\text { adjustment } \\
\text { buku pustaka } \\
\text { b.Memper- } \\
\text { baharui data } \\
\text { jumlah } \\
\text { ketersediaan } \\
\text { buku pustaka }\end{array}$ & $\begin{array}{l}\text { a.Sistem } \\
\text { berhasil } \\
\text { menampil- } \\
\text { kan form } \\
\text { adjustment } \\
\text { buku } \\
\text { pustaka } \\
\text { b.Sistem } \\
\text { berhasil } \\
\text { memper- } \\
\text { baharui } \\
\text { jumlah } \\
\text { ketersediaan } \\
\text { buku } \\
\text { pustaka }\end{array}$ \\
\hline $\begin{array}{l}\text { Unduh } \\
\text { laporan } \\
\text { adjust- } \\
\text { Ment }\end{array}$ & $\begin{array}{l}\text { Menekan } \\
\text { ikon } \\
\text { Microsoft } \\
\text { Office } \\
\text { Excel }\end{array}$ & $\begin{array}{l}\text { Sistem } \\
\text { mengunduh } \\
\text { laporan } \\
\text { adjustment } \\
\text { dalam bentuk }\end{array}$ & $\begin{array}{l}\text { Sistem } \\
\text { berhasil } \\
\text { mengunduh } \\
\text { laporan } \\
\text { adjustment }\end{array}$ \\
\hline
\end{tabular}

\begin{tabular}{|l|l|l|l|}
\hline & $\begin{array}{l}\text { dokumen } \\
\text { microsoft } \\
\text { office excel }\end{array}$ & $\begin{array}{l}\text { dalam } \\
\text { bentuk } \\
\text { dokumen } \\
\text { excel }\end{array}$ \\
\hline
\end{tabular}

\section{PENUTUP}

\subsection{Kesimpulan}

Berdasarkan hasil analisis dan implementasi Sistem Informasi Perpustakaan Teknik Lingkungan, UNDIP, dapat tarik beberapa kesimpulan sebagai berikut :

1. Penelitian yang dilakukan telah berhasil merancang dan mengimplementasikan sebuah Sistem Informasi Perpustakaan di Program Studi Teknik Lingkungan, Fakultas Teknik, UNDIP. Sistem informasi perpustakaan ini digunakan untuk memudahkan pengelolaan data dan aktivitas yang terjadi di Perpustakaan Teknik Lingkungan, Fakultas Teknik, UNDIP. Aktivitas yang ditangani adalah pengelolaan data pustaka, pengelolaan data laporan kerja praktek, pengelolaan data laporan tugas akhir, pengelolaan data anggota perpustakaan, pengelolaan transaksi peminjaman, perpanjangan, dan pengembalian buku, pengelolaan laporan pengadaan dan pertambahan buku, laporan peminjaman dan evaluasi perpustakaan, penyesuaian jumlah buku dan laporan (adjustment), serta pengelolaan data dengan fungsi import.

2. Sistem Informasi ini memiliki empat aktor, yaitu mahasiswa, dosen, karyawan, dan administrator.

3. Hasil Pengujian pada menu-menu diatas berhasil. Sistem bekerja secara handal dan akurat.

4. Sistem ini meningkatkan pelayanan dan efektifitas kinerja karyawan di Perpustakaan Teknik Lingkungan, Fakultas teknik, UNDIP. 


\subsection{Saran}

Berdasarkan hasil pengujian Sistem Informasi Perpustakaan Teknik Lingkungan, UNDIP, dapat diberikan beberapa saran sebagai berikut :

1. Sistem ini dapat dikembangkan dengan cara menambah menu untuk menampilkan abstrak buku yang dapat diunduh oleh anggota perpustakaan.

2. Pemberian barcode pada kartu anggota sehingga memudahkan transaksi peminjaman dan pengembalian buku.

\section{DAFTAR PUSTAKA}

Connoly; C, Begg. 2000. Database System, Edisi ke-3. California, USA : Addison Wesley Publishing Company Inc.

Date, C.J. 2000. An Introduction Database System. Volume 1, Edisi ke-7. California, USA : Addison Wesley Publishing Company Inc.

Ediwiyono, Wahyu A. 2007. Perancangan Sistem Pembelian Pada Distributor Outlet (Distro) Secara Online menggunakan PHP dan MySQL. Makalah Tugas Akhir Sarjana, tidak diterbitkan. Universitas Diponegoro, Semarang.

Http://ellislab.com/codeigniter/userguide/installation/downloads.html diakses pada tanggal 31 Mei 2013.

Https://www.oclc.org/content/dam/oclc/dewey /versions/print/intro.pdf diakses pada tanggal 31 Mei 2013.

Kadir, Abdul. 2008. Dasar Pemrograman Web Dinamis Menggunakan PHP-Edisi Revisi. Yogyakarta : ANDI.

Kadir, Abdul. 2009. Dasar Perancangan dan Implementasi Database Relasional.

Yogyakarta : ANDI.

Mahamudu, Billy N. 2010. Sistem Informasi. Artikel tidak diterbitkan.
Sidik, Betha. 2012. Framework CodeIgniter. Bandung: INFORMATIKA.

The ISBN Users' Manual International Edition Sixth Edition. 2012. London : International ISBN Agency. 